\title{
Islamic Branding and Digital Marketing: A Strategy to Attract Muslim Consumers Buying Interest
}

\author{
$1^{\text {st }} \mathrm{J}$ M Muslimin ${ }^{1}, 2^{\text {nd }}$ Sopian Lubis ${ }^{2}, 3^{\text {rd }}$ Reza Hendra Putra ${ }^{3}, 4^{\text {th }}$ Desi Nahartini ${ }^{4}$, \\ $5^{\text {th }}$ Ali Wafa ${ }^{5}$ \\ $\left\{\right.$ jm.muslimin@uinjkt.ac.id ${ }^{1}$, sopianlubis21@ mhs.uinjkt.ac.id², rezahendraputra21@ mhs.uinjkt.ac.id ${ }^{3}$, \\ desi@mhs.uinjkt.ac.id ${ }^{4}$, m.aliwafa@uinjkt.ac.id $\left.{ }^{5}\right\}$ \\ UIN Syarif Hidayatullah Jakarta $a^{1,2,3,4,5}$
}

\begin{abstract}
The increasing number of Muslim population and internet users has an impact on the global market. In the current global market conditions, both Muslim and nonMuslim producers are competing to develop products to get the Muslim market. In the company's competition to compete for consumer buying interest, it has been associated with brands and marketing methods. The researcher conducted an in-depth study and then formulated how the relationship between Islamic branding and digital marketing was. Then, why Islamic branding and digital marketing can be used as a strategy to attract consumer buying interest. This research is qualitative and uses a literature study approach. As a result, Islamic branding and digital marketing have a close relationship so that it can be used as a strategy in attracting consumer buying interest, especially Muslim consumers, considering the large Muslim market. Muslim producers who become business people must follow the current rapid technological developments to compete with other business actors, of course by using the concept of Islamic branding and digital marketing relations without eliminating the complete Islamic concept.
\end{abstract}

Keywords: Islamic Branding, Digital Marketing, Buying Interest

\section{Introduction}

Currently, in the competition for consumers, in other words, competition for business actors or companies is not only limited to functional attributes. Functional attributes in question such as product usability. Thus, in competition, companies to compete for consumer buying interest have been associated with brands that are able to provide a special image for the wearer, in other words, the role of the brand has shifted [1].

In its implementation, the brand is closely related to the strategy in attracting consumer buying interest. Thus, business actors or companies can strive not only to focus on services, product uses, and product models. However, it also focuses on branding or branding.

In the current global market conditions, both Muslim and non-Muslim producers are competing to develop products in order to get the Muslim market. There are three product categories that are targeted by producers[2]. First, Food, which is currently still dominated by non-Muslim multinational companies such as KFC, Danone, Nestle, and others. Second, Lifestyles, such as clothing, gadgets, cosmetics, and others, are also still dominated by nonMuslim multinational companies. Third, the service sector, such as banks, hospitals, hotels and others. In particular, Islamic banking services are currently dominated by Muslims, although it is possible that countries such as China, Britain, and France are also interested in developing 
this system. Products developed by manufacturers today are not far from Islamic branding considering the large Muslim market value.

The number of Muslims who have experienced a significant increase in recent years has attracted the attention of several companies. The Pew research institute also estimates this number will increase to 2.8 billion in 2050. Meanwhile, in Asia, Deloitte data shows that 1.05 billion Muslims occupied this continent in 2015. This number is equivalent to 62 percent of the total global Muslim population. Along with a large population, the Muslim market in Asia is starting to grow in various sectors; food, tourism, clothing, and media and recreation. Developments in this area have indeed begun to be seen since 2016. Furthermore, Statista estimates that the number of Muslim markets worth US\$2 billion in 2016 will increase to US\$3.08 billion by 2022 [3].

During a large Muslim market apart from using Islamic branding, nowadays, several companies use digital marketing as a way to get high purchasing power. Digital marketing is an effort or method to market a brand or product by using supporting media in digital form. Digital marketing can reach consumers both personally, relevantly, right on target according to the needs or desires of consumers.

The Indonesian Internet Service Providers Association (APJII) stated that there were 196.71 million Internet users in 2019-2020 out of a total population of 266.91 million in Indonesia [4]. Then, We Are Social and Hootsuite recorded internet users in Indonesia as many as 202.6 million people as of January 2021 [5]. From the data above, digital marketing can be a strategy in attracting consumer buying interest. From the Muslim population and internet users, it would be interesting to discuss how the relationship between the two and the strategy to attract Muslim consumers to buy.

From the presentation of the data above, researchers are interested in further observing how Islamic branding relates to digital marketing. Then, why Islamic branding and digital marketing can be used as a strategy to attract consumer buying interest. Thus, the researcher raised the title "Islamic Branding and Digital Marketing: A Strategy to Attract Consumers Buying Interest".

The results of research that have been carried out by previous researchers certainly have relevance to the research that researchers are currently studying, for a more comprehensive discussion as a comparison with research conducted by researchers. The research that is relevant to this research is. First, a research journal conducted by Dwi Wahyu Pril Ranto with the title "Creating Islamic Branding As A Strategy To Attract Consumer's Interest" discusses in detail the theory of Islamic branding and its implementation in order to create a brand image in order to attract massive consumer buying interest. In his writings, Islamic branding is a brand that has a close relationship with Islamic symbols. Then, his writing starts from the definition of a brand, the importance of building a brand, the phenomenon of Islamic branding, strategies to build Islamic branding, consumer buying interest, challenges and opportunities for marketing products and services using Islamic brands. Being different from current researchers is that it is not explained in detail how Islamic branding explores the digital market [6].

Second, writing in the form of a journal written by Muhammad Nasrullah with the research title "Islamic Branding, Religiosity And Consumer Decisions On Product". This study discusses Islamic branding in a structured way from understanding to implementation. Then, the purpose of this research is to find out whether Islamic branding has an effect on consumer decisions and whether religiosity strengthens the relationship between Islamic branding and consumer decisions in consuming products. The result of his research is that Islamic branding has a significant effect on consumer decisions to buy a product. What is interesting for researchers is that Islamic branding is influential than if it is connected at this time, which tends to be digital, 
is it also influential and has relationships. This is what makes this research different from previous research [7].

Third, the journal entitled "The Impact of Islamic Branding on Consumer Preference towards Islamic Banking Services: An Empirical Investigation in Malaysia" in this study shows that Islamic branding has a negative impact and an insignificant relationship with Islamic banking services because Malaysian consumers prefer Islamic banking services due to convenience services, service perception and ethical organization rather than Islamic brands. It is interesting to discuss that basically Islamic branding also has durability. Then, if understood comprehensively and fundamentally Islamic branding is only a strategy that is widely used by companies. Researchers, in this case, will look for the relationship between Islamic branding and digital marketing so that it has durability and can attract consumer buying interest [8].

\section{Methodology}

\subsection{Islamic Branding}

Kotler defines that a brand as a name, term, sign, or symbol, or a design, or a combination thereof, intended to identify a competitor's goods or services [9]. Then, another understanding comes from Tjiptono who states that the definition of a brand is as a name, term, symbol or symbol, design, color, motion or a combination of other product attributes that are expected to provide identity and as a differentiator to competitor products [10].

Based on the description, it can be concluded that the brand is a symbol or symbol given by the company to its products as a differentiator from other products. If a product has a good picture, it will have a positive impact on society or consumers. If a product has experienced problems that could defame the company, then the customer will indirectly switch to another product. So a brand is a seller's promise to consistently provide certain benefits and services to buyers. Brands are indispensable for a product because, in addition to having strong values, brands are also beneficial for consumers and producers, as well as society. The benefits of a brand according to Tjiptono are to identify and facilitate the tracking of similar products for companies, to protect a product in the eyes of the law, to determine the level of customer satisfaction with the product so that they will buy it again at another time, to create associations that can differentiate products from competitors, sources competitive advantage, and sources of financial return, especially regarding future income. Product brands have a positive value on consumer confidence in buying and consuming halal-labeled food because the halal label indicates that the product is halal. Islamic Branding is classified in three forms [11].

First, Islamic brand by compliance. Islamic brands must show and have a strong appeal to consumers by being obedient and obedient to Islamic sharia. Brands that fall into this category are halal products, produced by Islamic countries, and intended for Muslim consumers. Second, Islamic brand by origin. The use of the brand without having to show the halalness of the product because the product comes from the country of origin of the product is already known as an Islamic country. Such as Chiking Chicken originating from the United Arab Emirates (UAE). Third, Islamic brand by customer. This branding comes from non-Muslim countries but its products are enjoyed by Muslim consumers, for example, Multi-National companies, such as McDonald's, L'Oreal, Nestle, Unilever, KFC and so on. This branding usually includes a halal label on its products in order to attract Muslim consumers. 


\subsection{Digital Marketing}

Digital marketing is an effort or method to market a brand or product by using supporting media in digital form. Digital marketing is able to reach consumers both personally, relevantly, right on target according to the needs or desires of consumers [12]. The development of information technology and marketing through digital marketing is currently predicted to be a point of change in the technique of marketing a product where previously marketing conventionally switched to using digital marketing, not only on marketing elements but will have an impact on all business activities as a whole, whether it's a business that is already established. large-scale and national as well as individual businesses that have a small scale.

Therefore, business activity must be able to see opportunities to carry out effective marketing activities in the digital era at low and effective costs. Digital technology has changed the face of the business world, including marketing activities. Technology has changed the way humans speak, communicate, act, and make decisions. Technology has become very effective in maximizing the bottom line of an organization.

Digital Marketing is not a concept that focuses on technology [13], but on humans (marketers), namely how to understand humans (marketers), how to use technology in building relationships with other humans (customers) to build and significantly increase sales. Digital marketing never stops, it's even growing more rapidly day today. The use of the digital world is also increasingly useful not only in data transmission but also in many other fields. Digital marketing chronologically starts from the early 1980s, this is marked by the launch of the first personal computer (PC) by IBM in 1981. Then in 1990, the term digital marketing was introduced for the first time to the public. At that time a search engine was created called Archie. Archie's presence triggered a neater information collection system until the World Wide Web (www) was born in 1991. This appearance made people more interested in exploring the virtual world.

The result is that in just two years an online advertising banner was successfully created. The world's first e-commerce was born a year later with the name Yahoo! Exactly in 1994. In the 2010s era, the emergence of WhatsApp 2010 really influenced the trend of the digital world for years to come. Google also moved quickly by releasing its own social media platform called Google+. The giant Facebook also doesn't want to be left behind by intensifying the Facebook ads service with the greatness of the data bank they have. WhatsApp was also successfully acquired in 2014 by a company owned by Mark Zuckerberg. This shows how intense competition is in the digital world in this era.

Many marketers use Facebook, Twitter, Instagram, and Youtube to market their products, thus giving birth to a new innovation, namely mobile marketing. There are so many positive sides to using Mobile Marketing in carrying out a business activity such as a bank that will easily and quickly send transaction messages to customers, improve communication between employees without time limits, check schedules and information, reduce costs and increase productivity.

\subsection{Buying Interest}

Dwi Wahyu Pril Ranto (2013) in his journal entitled "Creating Islamic Branding As A Strategy To Attract Consumer's Interest" argues that buying interest is obtained from a learning process and a thought process that forms a perception. The interest that arises in making a purchase creates a motivation that continues to be recorded in his mind and becomes a very 
strong activity which in the end when a consumer has to fulfill his needs will actualize what is in his mind.

This buying interest is based on consumer behavior which will then act to decide whether to continue the purchase or not. Consumer behavior can also be defined as the actions consumers use to search for, decide on, use, evaluate and dispose of products and services in order to satisfy their needs. Consumer behavior is the action that is directly involved in obtaining, consuming and disposing of products and services, including the decision processes that precede and follow these actions [14].

There are many ways to attract consumer buying interest, one of which is building a brand in the community. In the process of building a brand, of course, it must be able to survive starting from the usability and efficiency of the product so that consumers are loyal. Consumer loyalty is grouped into two groups, namely brand loyalty and store loyalty [15]. For example, a consumer has very often made purchases of one brand of product. There is no longer a brand that is considered to be purchased other than the brand of products that he often buys. When the brand of the product is not available in the shop he goes to, he keeps trying to find the product even to faraway places. Even when the brand is not available, and the salesperson says the brand he is looking for will come a few days later, he is willing to wait for it. If there are consumers in their purchases that behave like that, then it can be said that consumers are very loyal to the brand of their choice and that is what is called brand loyalty. So, brand loyalty is a favorable attitude towards a brand that is represented in consistent purchases of that brand over time.

The definition of research method is a step that is carried out systematically and owned by a researcher in order to collect valid and relevant information or data needed by a researcher in finding answers to questions from research researchers.

This research is included in the type of qualitative research, research that emphasizes the aspect of deepening the data in order to get the quality of the results of a study. In this study, a qualitative approach was used to explore data or information related to Islamic branding, digital marketing, and buying interest. The approach used is the library research approach. The library approach explores deeply through documents, journals, books, and others [16]. The data in this study were obtained from library materials. Then in the analysis process using Content Analysis. This analysis is used to obtain valid inferences and can be reexamined based on the context. In this analysis, the process of selecting, comparing, combining and sorting various meanings will be carried out until the relevant ones are found. Then the data is reduced, presented or presented, and then conclusions are drawn.

\section{Result and Discussion}

\subsection{The relationship between islamic branding and digital marketing}

Seeing the development of technology and the rapid development of the population is one of the important relations between Islamic branding and digital marketing. The phenomenon that is currently happening is like the three big sharia-based banks in Indonesia, namely Bank BRI Syariah, Bank BNI Syariah, and Bank Syariah Mandiri which merged into one big name for a sharia-based bank, namely Bank Syariah Indonesia (BSI) so that the world's glasses protrude into Indonesia. It is proven that despite the pandemic, BSI can survive considering that it is in the midst of a Muslim-majority community and the majority use the internet [17]. The registration process to become a customer can be done online and announced online and grows 
in the Muslim community. So this is one of the visible relationships between Islamic branding and digital marketing.

If you look back at the definition of Islamic branding which emphasizes the usefulness of the product and consumer loyalty to the brand, digital marketing is also an important part of the process of consumers knowing the product and deciding to buy and be loyal to the product.

The researcher will describe the relationship scheme between Islamic branding and digital marketing, where Islamic branding and digital marketing have a very close relationship to the market in the digital world. So that consumers who actively use the internet have loyalty to these products.

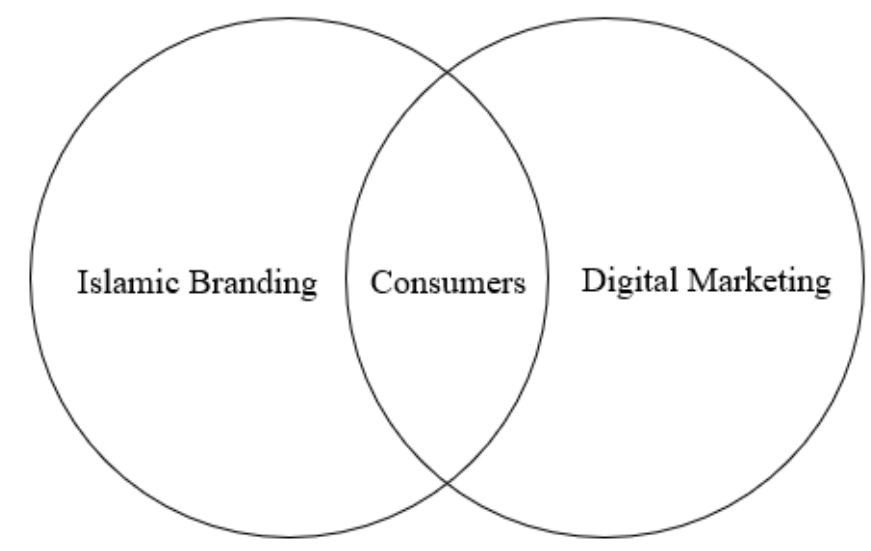

Fig. 1. Picture of the relationship between Islamic branding and digital marketing.

The schematic above is an illustration that the researcher shows that there is a very clear relationship between Islamic branding, digital marketing, and consumers. In the contest for the big Muslim consumer market, it is necessary to know what strategy is right to be used as a method to attract Muslim consumers to buy. Media skills can now be used as capital to expand market reach.

There are three dimensions in consumer behavior when deciding to make an online purchase that underlies a consumer to do electronic word of mouth. First, Tie strength describes how close and strong the relationship between information seekers about a product sold online, with the source of that information, such as consumers who have made online purchases. Second, Similarly (similarity) explains that the position of consumers is in the same group in terms of demographics and lifestyle. Third, source credibility (reliable source) is the perception of information seekers about a product sold online to the level of trustworthiness of the information source.

\subsection{Islamic Branding and Digital Marketing as Strategies to Attract Muslim Consumers}

The appearance of a unique or different brand is one form of marketing strategy to attract consumer buying interest. Brands are known to have an important role in influencing consumer purchasing decisions. Consumers before making a purchase decision will look for the right information related to the product or service that will be used. Usually, because they have limited time and information, consumers will base their decisions on brands that have proven quality and image. 
So it can be said that the appearance of a unique or different brand is needed to influence consumer interest in making a purchase. Islamic brands, as explained above, can make it easier for consumers to identify products or services that match their criteria. Islamic branding can be used as an attractive strategy to ask consumers to buy because the use of Islamic brands can be used as a brand that is different from other brands so that consumers can more easily remember the product considering that Islamic branding refers to Islamic elements both from services, products, places, prices, and others.

Conditions in the era of the industrial revolution 4.0 and society 5.0, digital marketing strategies play a very important role in building networks, communicating with consumers, and introducing a company's products or services. The digital media that are commonly accessed in implementing digital marketing strategies are websites, blogs, and also social media (Facebook, Instagram, Whatsapp, Line, etc.), SEO, SEM, Email Marketing, Content Marketing, Branding, and App Development.

Social media marketing can be done by anyone, as long as they have a social network account, they can do marketing focused on the target, social media marketing requires patience because of the opportunity to give up a big marketer. Several important components must be present in social media marketing, namely, first, sales conversions cannot be seen directly. People are convinced to want to buy. For this reason, promotions here must be carried out regularly and attractively. Second, build credibility. Third, attract potential customers. Fourth, share accurate content. Fifth, create valuable content. Sixth, use good and attractive images. Seventh, Crowdsource for interesting and Authentic content.

If you look at the relationships that occur, the strategy of attracting consumer buying interest by using Islamic branding and digital marketing has an opportunity in the Muslim market. The use of Islamic brands is expected not to eliminate the existing Islamic concept. Then the concept of modernity by using digital marketing in attracting Muslim consumers' buying interest is a very interesting relationship between Islam and modernity.

\section{Conclusion}

The relationship between Islamic branding and digital marketing provides a new point of view in the world of economic marketing. A strategy by combining the concepts of Islam and modernity is expected to be able to attract such a large buying interest of Muslim consumers. This relationship supports the realization of brand loyalty by Muslim consumers because Islamic branding uses concepts following Islamic provisions. The researcher concludes that Islamic branding and digital marketing can be used as a strategy in attracting consumer buying interest, especially Muslim consumers.

Then the researcher suggested, considering Indonesia as the largest Muslim country in the world, of course, Muslim producers who become business people must follow the current rapid technological developments to be able to compete with other business people. Muslim producers carry out marketing activities by Islamic principles. Doing business in Islam is highly recommended, of course, it must be by business ethics in Islam. The relationship between Islamic branding and digital marketing is one of the steps to answer market needs that dream of implementing a business that is by religious values and rules. 


\section{References}

[1] Aaker, David, A.: Managing Brand Equity, Capitalyzing on the Value of a Brand Name. The Press, New York. pp. 45-46 (1991)

[2] Nasrullah, Muhammad: Islamic Branding, Religiusitas Dan Keputusan Konsumen Terhadap Produk. Volume 13, Nomor 2, pp. 2. Jurnal Hukum Islam (JHI), Desember (2015) https://doi.org/10.28918/jhi.v13i2.487.

[3] Nadhifah, Ainun: Mengurai Potensi dan Tantangan Pasar Muslim di Asia. https://id.techinasia.com/potensi-dan-tantangan-pasar-muslim-di-asia (2019).

[4] APJII: Laporan Survei Internet APJII 2019-2020 (Q2). pp. 15 (2019)

[5] Wearesocial.com: Digital 2021 Indonesia. https://wearesocial.com (2021)

[6] Wahyu Pril Ranto, D: Menciptakan Islamic Branding Sebagai Strategi Menarik Minat Beli Konsumen. no. 2, pp. 11 (2013).

[7] Nasrullah, Muhammad: Islamic Branding, Religiusitas Dan Keputusan Konsumen Terhadap Produk, Jurnal Hukum Islam (JHI), pp. 79 ( 2015) https://doi.org/10.28918/jhi.v13i2.487.

[8] Abdul Jalil and Muhammad Khalilur Rahman: The Impact of Islamic Branding on Consumer Preference towards Islamic Banking Services: An Empirical Investigation in Malaysia, pp. 22. Journal of Islamic Banking and Finance 2 (2014)

[9] Kotler dan Keller: Manajemen Pemasaran. Jilid 1 Edisi ke 13, pp. 27. Erlangga, Jakarta (2009)

[10] Tjiptono, Fandy: Manajemen Pemasaran, Ed12. Jilid 2, pp. 36. PT Indeks, Jakarta (2007)

[11] Baker, Ahmad: On Islamic Branding: Brands as Good Deeds. Vol. 1 No. 2. Pp: 101-106. Journal of Islamic Marketing (2010)

[12] Musnaini: Digital Marketing. CV. Pena Persada, Jawa Tengah. pp. 21 (2020)

[13] Ryan: Understanding Digital Marketing. Kogan Page Limited Great Britain. pp. 12 (2014)

[14] Engel, Blackwell and Miniard: Perilaku Konsumen. Edisi Ke-Enam, Jilid 2. Binarupa Aksara, Jakarta. pp. 79 (1995)

[15] J. Setiadi, Nugroho: Prilaku Konsumen. edisi revisi. Kencana, Jakarta. pp. 125 (2010)

[16] Klaus, Krippendoff: Analisis Isi: Pengantar Teori dan Metodologi. Citra Niaga Rajawali Press, Jakarta. pp. 24 (1993)

[17] Segara Gustanto, Edy: Optimisme Perbankan Syariah di Masa Pandemi. Kumparan https://kumparan.com/edo-segara-1631670379140068854/optimisme-bank-syariah-di-masa-pandemicovid-19-1wX4C6g1d7e/4 (2021) 